\title{
Mortality and incidence of cancer among oil exposed workers in a Norwegian cable manufacturing company Part 2 Mortality and cancer incidence 1953-84
}

\author{
A RØNNEBERG,' A ANDERSEN, ${ }^{2}$ K SKYBERG ${ }^{3}$
}

From the Occupational Hygiene and Safety Department,' Standard Telefon og Kabelfabrik A/S, PO Box 60 Qkern, N-0508 Oslo 5, Cancer Registry of Norway, ${ }^{2}$ Montebello, N-0310 Oslo 3, and Institute of Occupational Health, ${ }^{3}$ Oslo, and Medical Department, Standard Telefon og Kabelfabrik A/S, Oslo, Norway

ABSTRACT Mortality and incidence of cancer 1953-84 was studied in a cohort of 529 men exposed to mineral oils in a Norwegian cable manufacturing company. Expected numbers of deaths were calculated from national death rates and cases of cancer from regional incidence rates. Among the 195 men who had worked for less than one year, there were statistically significant excesses of deaths from all causes $(\mathrm{O} / \mathrm{E}=75 / 39 \cdot 3)$ and from malignant neoplasms, ischaemic heart disease, non-malignant respiratory disease, and violence. In a subcohort of all 248 men with known work category and at least one year's employment in oil exposed work statistically significant excesses of deaths from ischaemic heart disease $(O / E=26 / 16 \cdot 1)$ and cases of lung cancer $(O / E=10 / 3 \cdot 9)$ were observed. Nine of the cases of lung cancer had occurred 20 years or more after first employment $(2.7$ expected; $\mathrm{p}<0.01$ ). In smokers of this subcohort there were 7.06 cases of lung cancer per 1000 person-years compared with 1.30 in smokers of a general population sample. It is concluded that exposure to mineral oils has probably been an important contributing factor in the development of lung cancer among these workers.

Exposure to mineral oils occurs during the manufacture of high voltage cables with oil impregnated paper insulation. An increased risk of skin cancer has been reported in oil exposed workers in other industries ${ }^{1}$ and there is also some evidence of excess risk of gastrointestinal, ${ }^{23}$ sinonasal, ${ }^{4}$ and lung cancer. ${ }^{5-7}$ We are not aware of any previous study of mortality or incidence of cancer among employees of the oil impregnated cable industry. The present investigation concerned a Norwegian cable plant in Oslo which has manufactured cables with oil impregnated paper insulation since the early $1920 \mathrm{~s}$. An increased prevalence of lung fibrosis has previously been reported in oil exposed workers at this plant, ${ }^{8}$ and there has been concern among the workers that exposure to cable oils might increase their risk of dying from chronic respiratory disease or cancer. The present study was initiated to investigate mortality and incidence of cancer among all workers ever employed in oil exposed work at the plant.

Accepted 24 August 1987

\section{Exposure conditions}

Exposure occurred during impregnation of paper insulated conductors with oils, extrusion of metal jackets on to the impregnated insulation in sheathing presses, and installation of cable joints in the field. Exposures to chemicals in this work have been described elsewhere. ${ }^{9}$ The oils used may be classified according to viscosity at $40^{\circ} \mathrm{C}$ as high viscosity oils $\left(500-2000 \mathrm{~mm}^{2} / \mathrm{s}\right)$, low viscosity oils $\left(2-7 \mathrm{~mm}^{2} / \mathrm{s}\right)$, and transformer oils $\left(15-30 \mathrm{~mm}^{2} / \mathrm{s}\right)$. Most oils were of naphthenic origin and had undergone only limited refining. High viscosity oils were used in impregnation and sheathing during the period $1920-40$ and in all three areas from 1946. Transformer oils were used in impregnation and sheathing from 1940 to 1945 and in installation from 1941 to 1970 . Low viscosity oils were used in all three areas from 1946.

The high viscosity oils have been present mainly as aerosols in the workroom air and exposure measurements suggest that time weighted average (TWA) oil mist levels have been $0.5-4 \mathrm{mg} / \mathrm{m}^{3}$ in all 
three areas. The more volatile low viscosity oils have been present mainly in the vapour phase and measurements suggest that TWA vapour levels have been within $10-50 \mathrm{mg} / \mathrm{m}^{3}$ in installation. No vapour measurement was performed in the other two areas but exposure to low viscosity oils was probably higher in impregnation and much lower in sheathing. Definite exposure to asbestos occurred in sheathing until the late 1950 s, whereas only minor exposures occurred in impregnation and installation.

\section{Study population}

The company's personnel records held cards for everyone employed since the plant was established in 1916. Each card contained the name, date of birth, and all dates of employment in or termination from any department of the company. Impregnation, sheathing, and cable armouring took place in one department until 1949, when a separate department for impregnation and sheathing was formed. The installation department was established in 1941. The study population was defined as all those individuals who had been employed for at least one day as an hourly salaried worker in one of these departments between 1 January 1920 and 31 December 1979. Individuals who satisfied this criterion were selected from the company's personnel records and selection was double checked against the departments' payrolls from 1 January 1953, 1958, 1964, 1970, and 1977. The admission criterion was satisfied by 550 individuals, all men.

For all individuals name, date of birth, date of first employment, and cumulative employment period in the departments of interest were obtained from the personnel records. Employment data were incomplete for two men and 19 individuals were lost to complete follow up. Of the latter, 16 men had left the company before national registration of cancer started on 1 January 1953. After exclusion of these 21 individuals, the final cohort consisted of 529 participants.

The 195 individuals who had worked less than one year were treated as one subcohort, whereas the 334 men with at least one years cumulative employment were divided into two groups.

The impregnation, sheathing, and installation subcohort of 248 men of known work category included 60 impregnation workers, 101 sheathing workers, and all 87 installation workers. All but two individuals in this subcohort had worked in 1950 or later.

The unspecified production subcohort of 86 individuals of unknown work category included 11 men who had left impregnation or sheathing before 1962 and all 75 workers who had left impregnation, sheathing, or armouring before 1950 . This subcohort was diluted with an unknown number of armouring workers with no known exposure to mineral oils.

Medical records for workers who had left the company after 31 December 1959 were available from the company's medical department. Current smoking habits had been recorded at the first medical examination since 1947 and later annually or biannually during employment. Of the 248 members of the impregnation, sheathing, and installation subcohort, 197 men could be classified through the medical records as smokers or non-smokers, and 39 of the remaining 51 men in this subcohort could be classified through interviews with three individuals who had worked together with the person in question. A participant was classified as a smoker if recorded as such at least once while employed by the company or if at least two individuals stated that he had smoked, whereas smoking habits were defined as unknown if only one individual could give information. No attempt was made to obtain data on type of smoking or amount smoked.

\section{Analysis of mortality and incidence of cancer}

Since 1 January 1953 all new cases of cancer in Norway have been recorded by the Cancer Registry of Norway. Registration is based on compulsory reporting of all cases of cancer by hospital departments and histopathological laboratories. All death certificates are coded by the Central Bureau of Statistics and this information has been given regularly to the Cancer Registry since 1 January 1953. A personal identification number was given to all individuals in Norway in 1960 and since then at birth or immigration.

The study cohort was observed for mortality and incidence of cancer from 1 January 1953 to 31 December 1984. A participant was followed up from 1 January 1953 or, if first employed later, from the middle of that year. Observation was continued until the middle of the year of death or to 31 December 1984. Participants who died or developed cancer in 1960 or later were identified automatically by using the personal identification numbers, whereas deaths or cases of cancer occurring before 1960 had to be identified manually.

The study was based on a comparison of observed and expected number of cases of cancer and deaths in the cohort during the observation period. The last known address of more than half of the cohort was Oslo. Expected numbers of cases of cancer were calculated from incidence rates for five year age groups for each year from 1953 to 1984 for men residing in Oslo. Death rates were not available for the male population in Oslo and the expected numbers of deaths were therefore calculated from national death rates. Standardised mortality ratios (SMRs) were calculated for total mortality and for selected causes of 
Table 1 Observed $(O)$ and expected $(E)$ numbers of deaths from selected causes among 529 cable workers 1953-84

\begin{tabular}{|c|c|c|c|c|c|c|c|c|}
\hline \multirow[b]{2}{*}{ Cause of death (ICD, 8th rev) } & \multicolumn{4}{|c|}{ Employed $<1$ year $(n=195)$} & \multicolumn{4}{|c|}{ Employed $\geqslant 1$ year $(n=334)$} \\
\hline & $O$ & $E$ & $S M R$ & $95 \% C I$ & $O$ & $E$ & $S M R$ & $95 \% C I$ \\
\hline $\begin{array}{l}\text { All causes } \\
\text { Malignant neoplasms }(140-209) \\
\text { Circulatory disease }(390-458): \\
\text { Ischaemic heart disease (410-414) } \\
\text { Non-malignant respiratory disease (460-519) } \\
\text { Violent death (E800-E959) } \\
\text { Other causes }\end{array}$ & $\begin{array}{r}75 \\
17 \\
32 \\
22 \\
6 \\
9 \\
11\end{array}$ & $\begin{array}{r}39 \cdot 3 \\
9 \cdot 2 \\
19 \cdot 0 \\
13 \cdot 7 \\
2 \cdot 0 \\
2 \cdot 9 \\
6 \cdot 2\end{array}$ & $\begin{array}{l}191^{* *} \\
185^{*} \\
168^{*} \\
161^{*} \\
297^{*} \\
311^{* *} \\
177^{*}\end{array}$ & $\begin{array}{r}150-301 \\
108-296 \\
115-238 \\
101-243 \\
109-647 \\
142-591 \\
89-317\end{array}$ & $\begin{array}{r}97 \\
24 \\
51 \\
40 \\
4 \\
7 \\
11\end{array}$ & $\begin{array}{r}86 \cdot 7 \\
19 \cdot 8 \\
43 \cdot 3 \\
29 \cdot 7 \\
5 \cdot 2 \\
5 \cdot 4 \\
13 \cdot 0\end{array}$ & $\begin{array}{r}112 \\
121 \\
118 \\
135 \\
76 \\
130 \\
85\end{array}$ & $\begin{array}{l}91-136 \\
78-180 \\
88-155 \\
96-183 \\
21-195 \\
52-269 \\
42-151\end{array}$ \\
\hline
\end{tabular}

${ }^{*} \mathrm{p}<0.05 ; * * \mathrm{p}<0.01$

death and standardised incidence ratios (SIRs) for all and selected cancer sites. For all SMRs and SIRs, $95 \%$ confidence intervals were determined by assuming a Poisson distribution for the observed number of deaths or cases of cancer. A result was regarded as statistically significant if the $95 \%$ confidence interval of the SMR or SIR did not include 100.

To study interactions with smoking, data on the incidence of lung cancer among smokers and nonsmokers in a sample of the general male population were required. These were derived from a study of the incidence of cancer during the period 1966-77 in a countrywide sample of 11979 Norwegian men born between 1895 and 1929 with smoking habits known from questionnaires in $1965 .^{10}$ Both past and present smokers were considered as smokers in this study. The crude age adjusted lung cancer incidence rates among smokers and non-smokers of this population sample and of the 236 cable workers with known smoking habits were calculated by using the direct standardisation method.

\section{Results}

The study cohort of 529 men was observed for the occurrence of death or cancer from the beginning of 1953 until the end of 1984, making up a total of 11433 person-years under observation. The 195 individuals with less than one year's employment represented 4197.5 person-years, the 248 participants of the impregnation, sheathing, and installation subcohort 5013.5 person-years, and the $86 \mathrm{men}$ in the unspecified production subcohort 2220 person-years.

Table 1 shows the observed and expected total mortality and mortality from selected causes. Among men with at least one year's employment, there was a total of 97 deaths compared with 86.7 expected. Excess deaths were caused by ischaemic heart disease (observed to expected ratio $\mathrm{O} / \mathrm{E}=40 / 29 \cdot 7$ ), malignant neoplasms $(O / E=24 / 19 \cdot 8)$, and violent death $(\mathrm{O} / \mathrm{E}=7 / 5.4)$ but not from non-malignant respiratory disease $(O / E=4 / 5 \cdot 2)$. A statistically significant excess of 75 deaths against 39.3 expected had occurred among men with less than one year's employment. Statistically significant excess mortality was observed from malignant neoplasms (observed/expected ratio, $\mathrm{O} / \mathrm{E}=17 / 9 \cdot 2)$, ischaemic heart disease $(\mathrm{O} / \mathrm{E}=$ $22 / 13 \cdot 7)$, non-malignant respiratory disease $(\mathrm{O} / \mathrm{E}=$ $6 / 2 \cdot 0)$, and violent death $(\mathrm{O} / \mathrm{E}=9 / 2 \cdot 9)$.

In table 2 the mortality from ischaemic heart disease is shown by years of employment. A statistically significant excess of deaths from this cause was observed in the impregnation, sheathing, and installation subcohort $(O / E=26 / 16 \cdot 1)$. Excesses in this subcohort were noted in participants who had worked for one to four years $(O / E=9 / 4.5)$ and among those who had worked for five years or more $(O / E=17 /$ 11.6). There was no increased mortality from ischaemic heart disease in the unspecified production subcohort $(O / E=14 / 13 \cdot 7)$.

Table 3 shows the number of new cases of cancer that occurred in the study cohort during the observation period. Although fewer cases of cancer than expected $(O / E=34 / 40.7)$ had occurred in workers employed for at least one year, a statistically significant excess of 14 cases of lung cancer compared with 7.2 expected was observed in this group. There

Table 2 Observed $(O)$ and expected $(E)$ numbers of deaths from ischaemic heart disease among 334 cable workers, 1953-84, by years of employment

\begin{tabular}{|c|c|c|c|c|c|c|}
\hline & \multirow{2}{*}{\multicolumn{2}{|c|}{ Total }} & \multicolumn{4}{|c|}{ Years of employment } \\
\hline & & & \multicolumn{2}{|l|}{$1-4$} & \multicolumn{2}{|l|}{$\geqslant 5$} \\
\hline & $o$ & $\boldsymbol{E}$ & $O$ & $E$ & $O$ & $E$ \\
\hline $\begin{array}{l}\text { Employed } \geqslant 1 \text { year: } \\
\text { Impregnation, sheathing, }\end{array}$ & 40 & 29.7 & 18 & $13 \cdot 3$ & 22 & $16 \cdot 4$ \\
\hline $\begin{array}{l}\text { Impregnation, sneatning, } \\
\text { and installation } \\
\text { Unspecified production }\end{array}$ & $\begin{array}{l}26^{*} \\
14\end{array}$ & $\begin{array}{l}16 \cdot 1 \\
13 \cdot 7\end{array}$ & $\begin{array}{l}9 \\
9\end{array}$ & $\begin{array}{l}4.5 \\
8.8\end{array}$ & $\begin{array}{r}17 \\
5\end{array}$ & $\begin{array}{r}11 \cdot 6 \\
4 \cdot 8\end{array}$ \\
\hline
\end{tabular}

* $p<0.05$. 
Table 3 Observed $(O)$ and expected $(E)$ numbers of selected types of cancers among 529 cable workers 1953-84

\begin{tabular}{|c|c|c|c|c|c|c|c|c|}
\hline \multirow[b]{2}{*}{ Cancer sites (ICD, 7th rev) } & \multicolumn{4}{|c|}{ Employed $<1$ year $(n=195)$} & \multicolumn{4}{|c|}{ Employed $\geqslant 1$ year $(n=334)$} \\
\hline & $O$ & $\boldsymbol{E}$ & SIR & $95 \% C I$ & 0 & $\boldsymbol{E}$ & SIR & $95 \% C I$ \\
\hline All cancer $(140-209)$ & 24 & $19 \cdot 2$ & 125 & $80-186$ & 34 & $40 \cdot 7$ & 84 & $58-117$ \\
\hline $\begin{array}{l}\text { Stomach (151) } \\
\text { Colon (153) } \\
\text { Rectum (154) } \\
\text { Lung }(162-163) \\
\text { Prostate (177) } \\
\text { Bladder (181) } \\
\text { Nervous system (193) } \\
\text { Lymphomas (200-202) } \\
\text { Other sites }\end{array}$ & $\begin{array}{l}3 \\
0 \\
0 \\
8 \\
1 \\
0 \\
1 \\
2 \\
9\end{array}$ & $\begin{array}{l}1.6 \\
1.4 \\
0.9 \\
3.5 \\
2.5 \\
1.4 \\
0.7 \\
0.6 \\
6.6\end{array}$ & $\begin{array}{l}192 \\
\overline{-} \\
\overline{227} \\
- \\
\overline{-} \\
\overline{336} \\
136\end{array}$ & $\begin{array}{c}40-562 \\
0-259 \\
0-418 \\
98-447 \\
1-220 \\
0-264 \\
4-822 \\
41-1215 \\
62-259\end{array}$ & $\begin{array}{r}1 \\
4 \\
3 \\
14 \\
4 \\
2 \\
1 \\
1 \\
4\end{array}$ & $\begin{array}{r}3 \cdot 4 \\
3 \cdot 1 \\
1 \cdot 9 \\
7 \cdot 2 \\
6 \cdot 5 \\
2 \cdot 9 \\
1 \cdot 2 \\
1 \cdot 2 \\
13 \cdot 3\end{array}$ & $\begin{array}{l}- \\
129 \\
157 \\
194^{*} \\
61 \\
68 \\
- \\
- \\
30^{* *}\end{array}$ & $\begin{array}{r}1-163 \\
35-331 \\
32-459 \\
106-325 \\
17-157 \\
8-245 \\
2-458 \\
2-478 \\
8-77\end{array}$ \\
\hline
\end{tabular}

$* p<0.05 ; *$ p $<0.01$

were 24 cases of cancer against 19.2 expected among those with less than one year's employment and an excess of cases of lung cancer was also noted in this group $(O / E=8 / 3 \cdot 5)$.

Table 4 shows the incidence of lung cancer in the three subcohorts by years since first employment. When follow up was started 20 years after first employment a statistically significant excess of cases of lung cancer was observed in men who had worked at least one year $(O / E=13 / 5 \cdot 8)$. This result was mainly due to an excess in the impregnation, sheathing, and installation subcohort $(\mathrm{O} / \mathrm{E}=9 / 2.7 ; \mathrm{p}<0.01)$. Four cases against $3 \cdot 1$ expected had occurred in the unspecified production subcohort. No excess of cases of lung cancer was observed when follow up was restricted to within 19 years from first employment $(\mathrm{O} / \mathrm{E}=1 / 1 \cdot 4)$. Among workers employed for less than one year there were two cases against 0.9 expected within 19 years from first employment and six cases against 2.6 expected when follow up started after 20 years.

The incidence of lung cancer in men with at least one year's employment was also analysed by years of employment (table 5). In the impregnation, sheathing, and installation subcohort excess cases were observed in men employed for one to four years $(\mathrm{O} / \mathrm{E}=3 / 1 \cdot 1)$ and in those who had worked for five years or more $(O / E=7 / 2.8 ; p<0.05)$, whereas all cases in the unspecified production subcohort had occurred in men with one to four years' employment $(O / E=4 /$ $2 \cdot 2)$. When the data were stratified according to year of first employment (table 6), a statistically significant excess of cases of lung cancer was observed in participants who started work in 1940 or later $(\mathrm{O} / \mathrm{E}=12 / 4.5 ; \mathrm{p}<0.01)$ but not among those employed before $1940(\mathrm{O} / \mathrm{E}=2 / 2 \cdot 8)$.

Of the 248 participants in the impregnation, sheathing, and installation subcohort, 190 men could be classified as smokers and 46 as non-smokers. Table 7 shows the distribution of these men by year of birth with their total mortality and mortality from lung cancer. The average age of the smokers was about ten years higher than that of the non-smokers. Ten of 43 deaths among smokers were caused by lung cancer whereas no lung cancers had occurred among the nonsmokers. Table 8 shows age adjusted incidence rates for lung cancer in cable workers with known smoking habits and in the general population sample. The rate per 1000 person-years was $\mathbf{0 . 2 2}$ for non-smokers and 1.30 for smokers in the general population sample, and 7.06 for the smoking cable workers. Since no cases had occurred in non-smoking cable workers, the incidence rate could not be calculated for this group.

\section{Discussion}

Statistically significant excesses of lung cancer (table 4) and deaths from ischaemic heart disease (table 2) were observed in the impregnation, sheathing, and installation subcohort. Both these diseases are related to smoking," and the possibility of confounding from different smoking habits in this subcohort and in the reference population must be considered.

Table 4 Observed $(O)$ and expected $(E)$ numbers of cases of lung cancer, 1953-84, by subcohort and years since first employment

\begin{tabular}{|c|c|c|c|c|c|c|}
\hline & \multirow{2}{*}{\multicolumn{2}{|c|}{ Total }} & \multicolumn{4}{|c|}{$\begin{array}{l}\text { Years since first } \\
\text { employment }\end{array}$} \\
\hline & & & \multicolumn{2}{|c|}{$0-19$} & \multicolumn{2}{|c|}{$\geqslant 20$} \\
\hline & $O$ & $E$ & $O$ & $E$ & $O$ & $E$ \\
\hline \multirow{2}{*}{$\begin{array}{l}\text { Employed }<1 \text { year } \\
\text { Employed } \geqslant 1 \text { year } \\
\text { Impregnation, sheathing, } \\
\text { and installation } \\
\text { Unspecified production }\end{array}$} & $\begin{array}{c}8 \\
14^{*}\end{array}$ & $\begin{array}{l}3.5 \\
7.2\end{array}$ & $\begin{array}{l}2 \\
1\end{array}$ & $\begin{array}{l}0.9 \\
1.4\end{array}$ & $13^{*}$ & $\begin{array}{l}2.6 \\
5.8\end{array}$ \\
\hline & $\begin{array}{c}10^{*} \\
4\end{array}$ & $\begin{array}{l}3.9 \\
3.3\end{array}$ & $\begin{array}{l}1 \\
0\end{array}$ & $\begin{array}{l}1.2 \\
0.2\end{array}$ & $\frac{9+}{4}$ & $\begin{array}{r}* 2 \cdot 7 \\
3 \cdot 1\end{array}$ \\
\hline
\end{tabular}

*p $<0.05 ; *$; $<0.01$.

IImpregnation $\mathrm{O} / \mathrm{E}=2 / 0 \cdot 9$, sheathing $\mathrm{O} / \mathrm{E}=4 / 1 \cdot 5$, installation $\mathrm{O} / \mathrm{E}=\mathbf{3 / 0 \cdot 4}$ 
Table 5 Observed $(O)$ and expected $(E)$ numbers of cases of lung cancer among 334 cable workers 1953-84, by years of employment

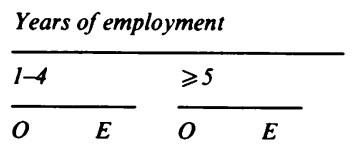

\begin{tabular}{llllll}
\hline Impregnation, sheathing, & & & & \\
$\quad$ and installation & 3 & $1 \cdot 1$ & $7^{*}$ & 2.8 \\
Unspecified production & 4 & $2 \cdot 2$ & 0 & $1 \cdot 1$ \\
\hline${ }^{*} \mathrm{p}<0.05$. & & &
\end{tabular}

There were $76 \%$ current smokers in members of the impregnation, sheathing, and installation subcohort who worked in $1960,72 \%$ in 1970 , and $57 \%$ in 1980 . By comparison, the prevalence of current smokers in Norwegian men aged 16 or older was $66 \%$ in 1960 , $55 \%$ in 1970 , and $42 \%$ in $1980 .{ }^{12}$ Polls taken in $1964-5^{13}$ and annually since 1973 (PM Lochsen, National Council on Smoking and Health, personal communication) show $10-15 \%$ higher prevalences of smoking among men in Oslo than in the whole country. Using these data and the method described by Axelson, ${ }^{14}$ expected increases in cardiovascular mortality and incidence of lung cancer from excess smoking among the cable workers were calculated to be less than $20 \%$. These calculations were based on death rates for lung cancer and ischaemic heart disease in male smokers and non-smokers reviewed by Steenland et al. "It may be concluded that the excess of cases of lung cancer and deaths from ischaemic heart disease in the impregnation, sheathing, and installation subcohort cannot be explained by excess smoking alone. This conclusion is also supported by the much higher incidence of lung cancer observed in smoking cable workers than in smokers of the general population (table 8).

The excess of cases of lung cancer in men with at least one year's employment was confined to the follow up period 20 years or more since first employment (table 4). This result is in accordance with an average latency of more than 20 years for occupational lung cancer and suggests that there has been a causal relation between employment in cable work and the development of lung cancer.

Results obtained by stratification of the material according to subcohort (table 4) and year of first employment (table 6) may suggest the presence of a temporal variation in the risk of lung cancer. The excess cases were confined to the impregnation, sheathing, and installation subcohort in which all but two subjects had worked in 1950 or later and to those in the unspecified production subcohort who started work in the 1940s. By contrast, there was no lung cancer among individuals in the unspecified production subcohort who started work before 1940, including all impregnation and sheathing workers who were employed before 1940 and left before 1950 . This pattern coincides with the introduction of low viscosity oils in 1946 and the increase in exposure to both low viscosity and high viscosity oils since 1950 .

Exposure to mineral oils has been verified for all members of the impregnation, sheathing, and installation subcohort through establishment of their work categories. Although it cannot be ruled out that exposure to asbestos dust may have contributed to the excess observed among the sheathing workers, we find it unlikely that such exposure might explain the excesses seen in the impregnation and installation work categories. Low viscosity and high viscosity mineral oils must therefore be considered as the most probable causes.

Interpretation of the excess lung cancer seen in members of the unspecified production subcohort who started work in the 1940s is made difficult by the inclusion of armouring workers without any exposure to mineral oils. The work category of each case is not known and some may well have occurred in armouring workers. It is also notable that the average employment period of the cases of lung cancer in the unspecified production subcohort was less than two

Table 6 Observed $(O)$ and expected $(E)$ numbers of cases of lung cancer 1953-84 in 529 oil exposed cable workers by period of first employment

\begin{tabular}{|c|c|c|c|c|c|c|}
\hline \multirow[b]{3}{*}{ Period of first employment } & \multirow{2}{*}{\multicolumn{2}{|c|}{ Employed $<1$ year }} & \multicolumn{4}{|c|}{ Employed $\geqslant 1$ year } \\
\hline & & & \multicolumn{2}{|c|}{$\begin{array}{l}\text { Impregnation, sheathing, } \\
\text { and installation }\end{array}$} & \multicolumn{2}{|c|}{ Unspecified production } \\
\hline & $O$ & $E$ & $O$ & $E$ & $O$ & $E$ \\
\hline $\begin{array}{l}1920-39 \\
1940-49 \\
1950-59 \\
1960-79\end{array}$ & $\begin{array}{l}0 \\
5 \\
2 \\
1\end{array}$ & $\begin{array}{l}0.2 \\
2.6 \\
0.5 \\
0.3\end{array}$ & $\begin{array}{l}2 \\
5 \\
3 \\
0\end{array}$ & $\begin{array}{l}0.5 \\
1.8 \\
1.2 \\
0.5\end{array}$ & $\begin{array}{l}0 \\
4^{*} \\
0 \\
0\end{array}$ & $\begin{array}{l}2 \cdot 3 \\
0 \cdot 9 \\
0 \cdot 1 \\
0 \cdot 0\end{array}$ \\
\hline
\end{tabular}

${ }^{*} \mathrm{p}<0.05$. 
Table 7 Distribution of deaths and cases of lung cancer by year of birth. Impregnation, sheathing, and installation workers with at least one year's employment and known smoking habits

\begin{tabular}{|c|c|c|c|c|c|c|c|c|}
\hline \multirow[b]{2}{*}{ Year of birth } & \multicolumn{4}{|c|}{ Non-smokers } & \multicolumn{4}{|c|}{ Smokers } \\
\hline & No & Per cent & Deaths & $\begin{array}{l}\text { Deaths from } \\
\text { lung cancer }\end{array}$ & No & Per cent & Deaths & $\begin{array}{l}\text { Deaths from } \\
\text { lung cancer }\end{array}$ \\
\hline $\begin{array}{l}\leqslant 1899 \\
1900-09 \\
1910-19 \\
1920-29 \\
1930-39 \\
1940-49 \\
\geqslant 1950\end{array}$ & $\begin{array}{r}1 \\
4 \\
4 \\
7 \\
7 \\
8 \\
15\end{array}$ & $\begin{array}{r}2.2 \\
8.7 \\
8 \cdot 7 \\
15 \cdot 2 \\
15 \cdot 2 \\
17.4 \\
32.6\end{array}$ & $\begin{array}{l}1 \\
2 \\
1 \\
- \\
- \\
- \\
-\end{array}$ & $\begin{array}{l}- \\
\overline{-} \\
- \\
\overline{-} \\
-\end{array}$ & $\begin{array}{r}2 \\
30 \\
34 \\
29 \\
31 \\
32 \\
32\end{array}$ & $\begin{array}{r}1 \cdot 1 \\
15 \cdot 8 \\
17.9 \\
15 \cdot 3 \\
16 \cdot 3 \\
16 \cdot 8 \\
16.8\end{array}$ & $\begin{array}{r}2 \\
21 \\
11 \\
5 \\
1 \\
2 \\
1\end{array}$ & $\begin{array}{l}1 \\
4 \\
4 \\
1 \\
- \\
- \\
-\end{array}$ \\
\hline Total & 46 & $100 \cdot 0$ & 4 & - & 190 & $100 \cdot 0$ & 43 & 10 \\
\hline
\end{tabular}

years as compared with 13 years in the impregnation, sheathing, and installation subcohort (not shown in tables).

The ratio between incidence rates for lung cancer in oil exposed smokers versus non-exposed smokers was 5.4 (table 8 ). This result may be compared with a rate ratio of 4.3 for asbestos exposed smokers versus nonexposed smokers reported from a Norwegian study that used the same general population sample..$^{\text {is }}$ It has been proposed that the mode of interaction between exposure to asbestos and smoking is multiplicative. ${ }^{16}$ This may be the case for interaction between exposure to oil and smoking as well, although one might also speculate that the increased risk for lung cancer among oil exposed workers manifests itself only in the presence of smoking. No conclusions may be drawn regarding the mode of interaction, however, since no cases of lung cancer were to be expected among the non-smoking cable workers due to their small number and young age (table 7).

The previous epidemiological evidence of a relation between lung cancer and exposure to mineral oils is equivocal. Excess mortality from lung cancer has been reported in newspaper workers exposed to printing inks containing mineral oil ${ }^{56}$ but not in metal workers exposed to cutting oils. ${ }^{2317}$ Exposure to mineral oils has been strongly and consistently associated with the occurrence of skin cancer, and particularly cancer of the scrotum.' Reliable calculations of expected numbers of skin carcinomas could not be performed in the present study but no scrotal cancers occurred in the cohort during the observation period. Excesses of gastrointestinal cancers have been reported from studies of oil exposed metal workers, ${ }^{23}$ but this is not confirmed by the present results. Two cancers of the colon (1.7 expected) and no ventricular or rectal cancers were observed in the impregnation, sheathing, and installation subcohort (not shown in tables).

Chemical differences between exposures reported here and those reported in other studies may provide an explanation of these apparent discrepancies. It has been shown experimentally that the carcinogenic potency of mineral oils varies widely with boiling point range and refining history. ${ }^{18}$ The boiling point range of the low viscosity cable oils is lower than for most other industrial oils whereas that of the high viscosity cable oils is higher. Exposure to potentially toxic additives is not believed to be important to the present results whereas such exposures may have influenced the results for gastrointestinal cancers in some previous studies. ${ }^{1-3}$

The choice of a proper reference population for calculation of expected rates is always critical in studies such as the present one. Mortality from ischaemic heart disease in men was $32 \%$ higher in Oslo than in the whole country in $1959-62,11 \%$ higher in $1971-5$, and $10 \%$ higher in 1976-80. ${ }^{19}$ Although not statistically significant after adjustment for these differences and smoking, an excess of deaths from ischaemic heart disease is still present in the

Table 8 Incidence of lung cancer in oil exposed cable workers and in a general population sample of Norwegian men with known smoking habits

\begin{tabular}{|c|c|c|c|c|c|c|c|}
\hline \multirow[b]{2}{*}{$\begin{array}{l}\text { Study } \\
\text { population }\end{array}$} & \multirow[b]{2}{*}{$\begin{array}{l}\text { Follow up } \\
\text { period }\end{array}$} & \multicolumn{3}{|c|}{ Non-smokers } & \multicolumn{3}{|c|}{ Smokers } \\
\hline & & $\begin{array}{l}\text { No of } \\
\text { cases }\end{array}$ & $\begin{array}{l}\text { No of } \\
\text { person- } \\
\text { years }\end{array}$ & $\begin{array}{l}\text { Age adjusted } \\
\text { rate per } 1000 \\
\text { person-years }\end{array}$ & $\begin{array}{l}\text { No of } \\
\text { cases }\end{array}$ & $\begin{array}{l}\text { No of } \\
\text { person- } \\
\text { years }\end{array}$ & $\begin{array}{l}\text { Age adjusted } \\
\text { rate per } 1000 \\
\text { person-years }\end{array}$ \\
\hline $\begin{array}{l}\text { General population sample } \\
\text { Oil exposed cable workers }\end{array}$ & $\begin{array}{l}1966-77 \\
1953-84\end{array}$ & $\begin{array}{l}9 \\
0\end{array}$ & $\begin{array}{r}29652 \\
435\end{array}$ & $\begin{array}{r}0 \cdot 22 \\
-\end{array}$ & $\begin{array}{r}116 \\
10\end{array}$ & $\begin{array}{r}93135 \\
2402\end{array}$ & $\begin{array}{l}1 \cdot 30 \\
7 \cdot 06\end{array}$ \\
\hline
\end{tabular}


impregnation, sheathing, and installation subcohort. This result may be due to random variation, but the absence of any such excess in the unspecified production subcohort (table 2) might suggest an association between ischaemic heart disease and work in impregnation, sheathing, and installation after 1945. No increase in cardiovascular mortality has been reported from previous studies of oil exposed workers. ${ }^{23517}$ Other work related risk factors than chemical exposure might deserve consideration but the protocol of the present study did not permit any analysis of their potential influence.

The absence of excess deaths from non-malignant respiratory disease in men who had worked at least one year (table 1) confirms the results from previous mortality studies of oil exposed workers. ${ }^{235617}$ Only one death from this cause against 2.8 expected was observed in the impregnation, sheathing, and installation subcohort (not shown in tables). This is of particular interest since a previous cross sectional study has showed an increased prevalence of slight pulmonary fibrosis in impregnation workers with at least five years' employment at the study plant of the present investigation. ${ }^{8}$

Excesses of cases of lung cancer and deaths from ischaemic heart disease and non-malignant respiratory diseases were observed in men who had worked less than one year (tables 1 and 3). All these diseases are related to smoking, ${ }^{11}$ but social factors and work conditions in other jobs may also have been important.

The present study has shown a statistically significant excess of cases of lung cancer in a small cohort of oil exposed cable workers. This result cannot be accounted for by excess smoking alone and exposure to non-severely refined, low viscosity, and high viscosity oils must be considered as an important causative factor. For reasons discussed above the results presented here are not necessarily relevant to all other types of mineral oils. Further follow up of this population and studies of other groups with well defined exposure to oils are needed before any firm conclusions may be drawn regarding the carcinogenicity of mineral oil products to the human lung.

We thank Bo Holmberg, National Board of Occupational Safety and Health, Sweden, and Rodolfo Saracci, International Agency for Research on Cancer, Geneva, for valuable comments. We are also grateful to Stefi Wetteland for her linguistic guidance.

\section{References}

1 International Agency for Research on Cancer. Monographs on the evaluation of the carcinogenic risk of chemicals to man. Polynuclear aromatic hydrocarbons. Part 2. Carbon blacks, mineral oils and some nitroarenes. Lyon: IARC, 1984.

2 Järvholm B, Lillienberg L, Sällsten G, Thiringer G, Axelson O. Cancer morbidity among men exposed to oil mist in the metal industry. J Occup Med 1981;23:333-7.

3 Decoufle P. Further analysis of cancer mortality patterns among workers exposed to cutting oil mists. JNCI 1978;61:1025-30.

4 Roush GC, Meigs JW, Kelly J, Flannery JT, Burdo H. Sinonasal cancer and occupation: a case-control study. Am J Epidemiol 1980;111:183-93.

5 Greenberg M. A proportional mortality study of a group of newspaper workers. Br J Ind Med 1972;29:15-20.

6 Moss E, Scott TS, Atherley GRC. Mortality of newspaper workers from lung cancer and bronchitis 1952-66. $\mathrm{Br} J$ Ind Med 1972;29:1-14.

7 Waldron HA. The carcinogenicity of oil mist. Br J Cancer 1975;32:256-7.

8 Skyberg K, Rønneberg A, Kamøy JI, Dale K, Borgersen A. Pulmonary fibrosis in cable plant workers exposed to mist and vapor of petroleum distillates. Environ Res 1986;40:261-73.

9 Rønneberg A, Skyberg K. Mortality and incidence of cancer among oil exposed workers in a Norwegian cable manufacturing company. Part 1. Exposure conditions 1920-79. Br J Ind Med 1988;45:589-94.

10 Lund E, Zeiner-Henriksen T. Smoking as risk factor for cancer in various sites among 26000 Norwegian men and women. Tidsskr Nor Lageforen 1981;101:1937-40. (In Norwegian.)

11 Steenland K, Beaumont J, Halperin W. Methods of control for smoking in occupational cohort mortality studies. Scand $J$ Work Environ Health 1984;10:143-9.

12 Zeiner-Henriksen T. Fewer men smoke daily. Mot Kreft No 1 1979:16-7. (In Norwegian.)

13 Zeiner-Henriksen T. Smoking habits in the Norwegian population. Tidsskr Nor Lageforen 1976;96:617-20. (In Norwegian.)

14 Axelson 0 . Aspects on confounding in occupational health epidemiology. Scand J Work Environ Health 1978;4:85-9.

15 Hilt B, Langård S, Andersen A, Rosenberg J. Asbestos exposure, smoking habits, and cancer incidence among production and maintenance workers in an electrochemical plant. Am J Ind Med 1985;8:565-77.

16 Hammond EC, Selikoff IJ, Seidman H. Asbestos exposure, cigarette smoking and death rates. Ann NY Acad Sci 1979;330:473-90.

17 Ely TS, Pedley SF, Hearne FT, Stille WT. A study of mortality, symptoms, and respiratory function in humans occupationally exposed to oil mist. J Occup Med 1970;12:253-61.

18 Lewis SC. Crude petroleum and selected fractions-skin cancer bioassays. Prog Exp Tumor Res 1983;26:68-84.

19 Central Bureau of Statistics. Regional mortality 1976-80. Oslo: CBS, 1982. 